\title{
LARVAL DEVELOPMENT OF PLAGIOSCION SQUAMOSISSIMUS (HECKEL) (PERCIFORMES, SCIAENIDAE) OF ITAIPU RESERVOIR (PARANÁ RIVER, BRAZIL)
}

\author{
Keshiyu Nakatani ${ }^{1}$ \\ Gilmar Baumgartner ${ }^{2}$ \\ Maria do Socorro T. Baumgartner ${ }^{2}$
}

\begin{abstract}
The aim of the present study was to characterize the larval development of Plagioscion squamosissimus (Heckel, 1840) morphometrically, collected at Itaipu reservoir from March 1988 to April 1990. It was obtained the samples monthly, with a conic-cylindrical plankton net with $0.5 \mathrm{~mm}$ mesh. The morphological description of the larvae of $P$. squamosissimus was based on different stages of development. The specimens less than $6 \mathrm{~mm}$ long present a moderate sized head and those that are larger than this length, present a large head. The pectoral fins are in an elevated position, near the operculum bones, and the ventral fins are in thoracic positions, the body has a moderate height, the eyes are small to moderate and the mouth is large with caniniform teeth. This species presents a proportional growth among the different parts of the body, as can be seen by the high correlation coefficient values $(r>0.98 ; \mathrm{p}<0.001)$.

KEY WORDS. Plagioscion squamosissimus, fish larvae, morphology, larval development, Itaipu
\end{abstract}

The family Sciaenidae, object of this study, has a marine origin, being represented by the genera Pachyurus (Agassiz, 1829), Pachypops (Gill, 1861) and Plagioscion (Gill, 1861) in fresh water (FowLER 1954). In Brazil; SOARES (1978) informs that Plagioscion squamosissimus (HECKEL 1840) is endemic to the Amazon basin. However, SILVA \& MENEZES (1950) state that the habitat of this species also includes the Parnaiba river basin. P. squamosissimus was introduced in 1967 to the Pardo river, states of São Paulo and its distribution increased to include the lower stretches of the Paraná river (NOMURA 1984; TORLONI et al. 1993). This species is popularly known as "curvina", "corvina", "cruvina", "pescada-do-piauí", "pescada", "corvina-do-rio", "pescada-cacunda", "pescada-amarela", "pescada-foguete", "tortinha", "soleira" (RINGUELET et al. 1967; NOMURA 1984).

SOARES (1978) characterized the adults of $P$. squamosissimus as presenting a long and slightly compressed (fusiform) body; large head; large and terminal mouth; maxilla with canine and villiform teeth; operculum with one or two lamellar

1) Departamento de Biologia, Nupélia, Universidade Estadual de Maringá. Avenida Colombo 5790, 87020-900 Maringá, Paraná, Brasil.

3) Curso de Pós-graduação em Ecologia de Ambientes Aquáticos Continentais, Universidade Estadual de Maringá. Avenida Colombo 5790, 87020-900 Maringá, Paraná, Brasil. 
spines; non-dented pre-operculum, with some fragile spines and a well-developed membrane. ANNIBAL (1983) completes this information stating that the species possesses approximately 11 spines and 19 soft rays on the dorsal fin.

In the Paraná river basin, most of the existing papers about the curvina are related to its feeding diet, aspects of gonadal maturation, net selectivity and fishery production (ITAIPU BINACIONAL 1981; MOTA et al. 1984; FUEM/ITAIPU BINACIONAL 1989, 1990a,b; AGOSTINHO et al. 1989; CRUZ et al. 1990; HAHN 1991; TORLONI et al. 1993). An exception is NAKATANI et al. (1993), who studied the spatial and temporal distribution of the larvae of this species at the Itaipu reservoir.

Aiming at the identification of the species, the present paper had as its objective, contribute to the knowledge about the morphological alterations in the initial phase of the life cycle of Plagioscion squamosissimus (Heckel, 1840), by series characterization of the larval development and analysis of morphometric measurements.

\section{MATERIAL AND METHODS}

The larvae was captured from March, 1988 to February, 1990, in 38 sampling stations along the Itaipu reservoir.

It was used a conic-cylindrical plankton net with $0.5 \mathrm{~mm}$ mesh and length of $1.5 \mathrm{~m}$ for the sampling. The material prevalent from the collections was fixed in a solution of neutral formaline (4\%). The larvae were sorted and measured under a stereoscopic microscope. The drawings were made with a drawing tube attached to the microscope.

For identification of the larvae it was used the development series proposed by AHLSTROM \& MOSER (1976). The division of the larvae in stages (pre-flexion, flexion and post-flexion) follows the development sequence of the caudal fin, its supporting elements and the notochord, according to AHLSTROM \& BALL (1954) and KENDALL et al. (1984). The terminology used for the morphometry follows those defined by AHLSTROM et al. (1976), while the body proportions follow the categories proposed by LEIS \& TRNSKI (1989).

Correlation studies were undertaken between: a) length of the head, pre-anal distance, pre-dorsal distance and height of the body in relation to standard length; b) diameter of the eye in relation to the length of the head, using the equation:

$$
Y=a+b . X
$$

\section{RESULTS}

\section{Morphometric characteristics of the larvae}

The morphological description of larvae of $P$. squamosissimus is based on individuals whose size is comprehended between 4.5 and $17.2 \mathrm{~mm}$ of standard length (SL) (Figs 1-2), that integrate different stages of development of the species.

The larva of $4.5 \mathrm{~mm}$ SL (Fig. IA) is in the flexion stage, having begun the flexing of the notochord. The dorsal, anal and caudal fins present the beginning of 
ray formation, and are covered by an embryonic membrane extending from the head to the anus. The head is rounded, with little pigmentation. The mouth is large, with visible teeth in the upper and lower maxilla. The operculum opening is well defined, with the presence of the first opercular spines. The eyes are visible and pigmented. In the body, it is possible to observe the myomeres being formed and, by transparency, the notochord. The anus is well defined and the intestine is relatively short. The pectoral fin is present, surrounded by a membrane, with traces of ray formation.

The body of the larva of $5.75 \mathrm{~mm}$ SL (Fig. 1B) presents various changes. It becomes taller and the myomeres are visible. At this size, the post-flexion stage is present, due to the flexing of the notochord in the caudal region. The transparent membrane suffered a small reduction and the supporting elements of the rays of the dorsal, caudal and anal fins have become more evident. In this phase of development we can evidence the rays of the pectoral fin and the beginning of its development. The head and trunk are relatively robust. The spines of the operculum and pre-operculum have increased in number and size. The mouth is large and oblique, showing teeth on the upper and lower maxilla. The digestive tract still presents a ventral protuberance and the anus is situated before the median portion of the body. The chromatophores distribute themselves sparsely in the cephalic region.

The larva of $6.6 \mathrm{~mm}$ SL (Fig. 1C) is also in the post-flexion stage. The transparent membrane has practically disappeared with the formation of the supporting elements of the dorsal, caudal and anal fins. The rays of the fins are relatively well developed, except for the dorsal fin spines, that are still short. Close to the eyes we observe the formation of orbital spines. The spines of the operculum and pre-operculum are much larger, when compared to the preceding stage. The rays of the caudal fin are becoming longer in the portion of the median line of the body. The pigmentation is restricted to the cephalic region, although at a higher density. The ventral fin still presents rays in the formation phase.

The embryonic membrane of the larva of $7.1 \mathrm{~mm}$ SL (Fig. 2A) has totally disappeared. The shape of the body has varied little in relation to the preceding phase. The spines of the dorsal and anal fins are differentiated from the soft rays. The ventral fin, that in the anterior phase was not very visible, has now become extremely evident. The caudal fin presents well-developed median rays of the body. The spine-like structures of bone nature increase in the head region. The chromatophores present at the base of the anal fin become evident. The digestive tract is more developed than in the preceding stage. The anus opens in the median portion of the body, at the base of the anal fin.

The larva of $12 \mathrm{~mm}$ SL (Fig. 2B) presents a well-defined body shape. Practically all the morphological structures are consolidated. The rays of the fins are nearly completely formed. The spines of the operculum and pre-operculum are more developed and defined in relation to the preceding stage. The chromatophores have increased in number at the base of the anal fin, being observed also in the membrane that surrounds the spines of the dorsal fin. The bones of the operculum are more prominent in the posterior region of the head, partially covering the base of the pectoral fins. The mouth is well developed, with many small teeth present on the upper and lower maxillae. 

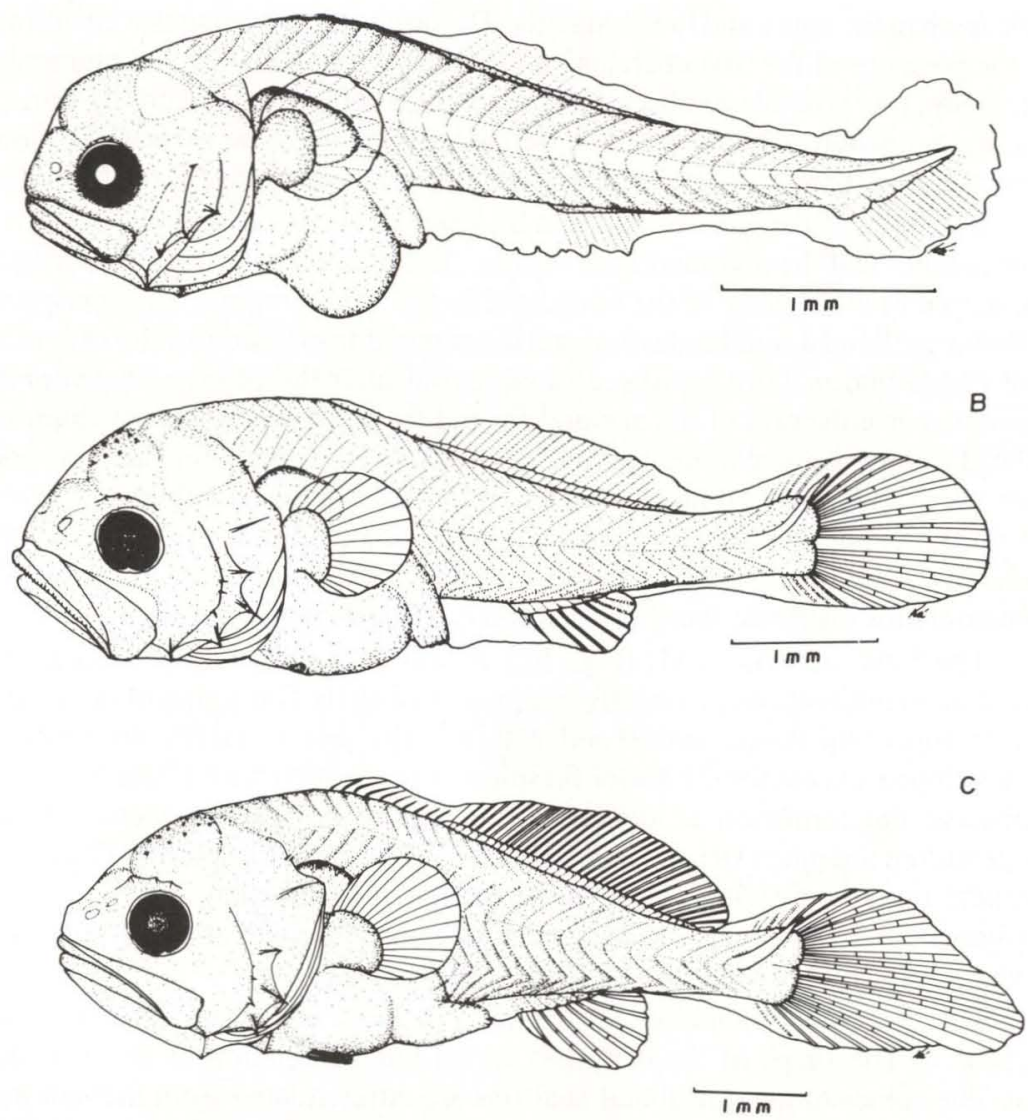

Fig. 1. Larvae of Plagioscion squamosissimus (HECKEL, 1840) from Itaipu reservoir: A) 4,5mm $\mathrm{SL}$ (flexion); B) 5,75mm SL (post-flexion) and C) 6,6mm SL (post-flexion).

The juvenile individual of $17.2 \mathrm{~mm}$ SL (Fig. 2C) presents completely formed fins. The median rays of the caudal fin, especially those under the median line, are longer. The spine-like structures have appeared in greater number around the eyes. The pigments increased considerably, being more dense in the membrane that covers the spines in the dorsal region, in the upper part of the head and at the base of the anal, caudal and dorsal fins. The spines of the operculum and pre-operculum are more numerous and larger than in the preceding stage.

\section{Body proportions}

The morphometric parameters, modified in a short period of the larval growth of $P$. squamosissimus, showed great variation in body proportions. Therefore, the length of the head at the final phase of flexion fits into the "moderate head" 


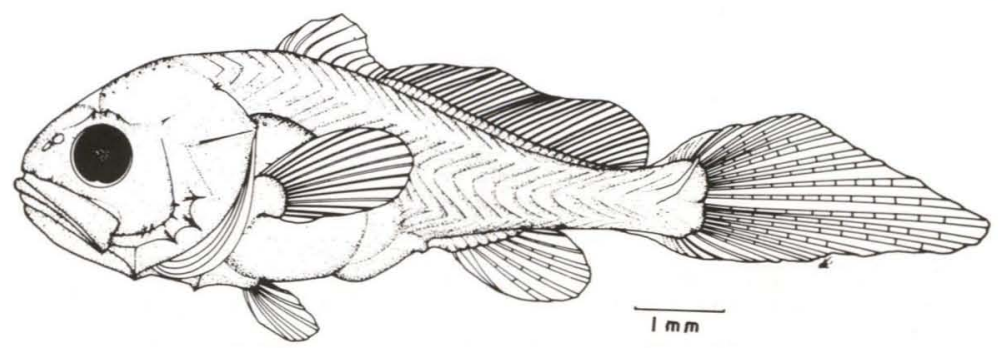

B
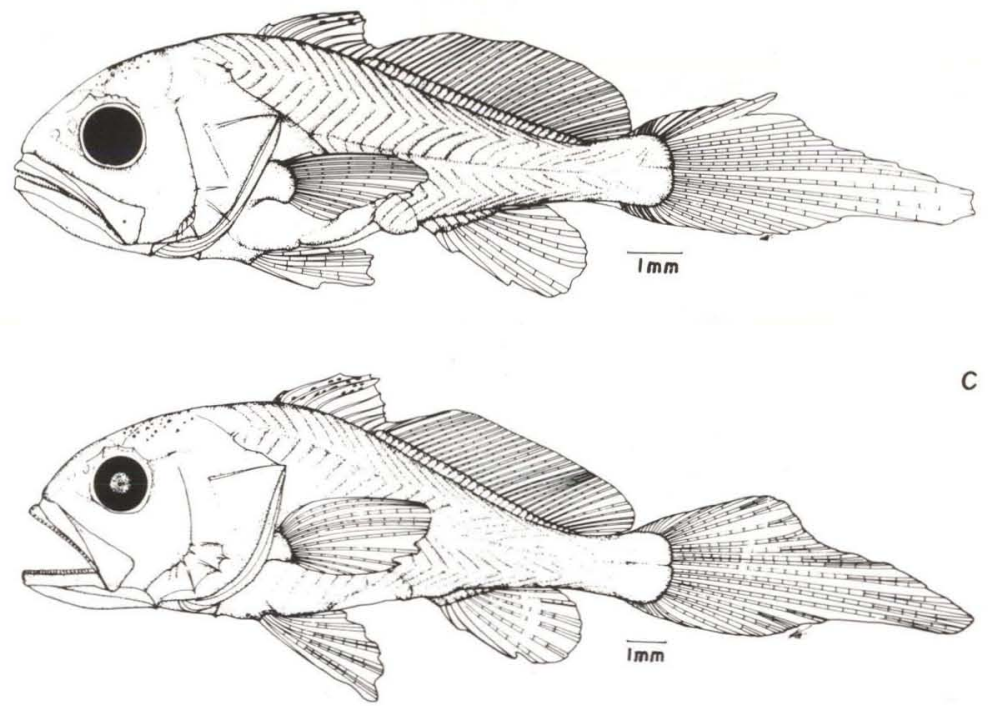

Fig. 2. Larvae of Plagioscion squamosissimus (Heckel, 1840) from Itaipu reservoir: A) $7.1 \mathrm{~m}$ $\mathrm{SL}$ (post-flexion); B) $12 \mathrm{~mm} \mathrm{SL} \mathrm{(post-flexion)} \mathrm{and} \mathrm{C)} 17.2 \mathrm{~mm}$ SL (juvenile).

category, with values varying from 20 to $35 \%$ in relation to the standard length, until $6 \mathrm{~mm}$. In the next phase (post-flexion), it becomes proportionally larger, now representing the "large head" with values varying from 33 to $42 \%$ of the SL (Fig. $3 \mathrm{~A})$

The height of the body fits into the "moderate" category, with values varying between 20 and $40 \%$ in relation to the standard length (Fig. 3B). The pre-dorsal distance in larvae larger than $3 \mathrm{~mm}$ long (pre-flexion) varied from 35 to $42 \%$ of the SL (Fig. 3C). The measurement of the pre-anal distance was only possible in larvae larger than $6 \mathrm{~mm}$ (end of flexion), presenting values varying from 60 to $67 \%$ of the SL (Fig. 3D).

The diameter of the eye fits into the "small to moderate eye" category, presenting variations between 15 to $40 \%$ of the length of the head (mean of $25 \%$ ) (Fig. 3E). 

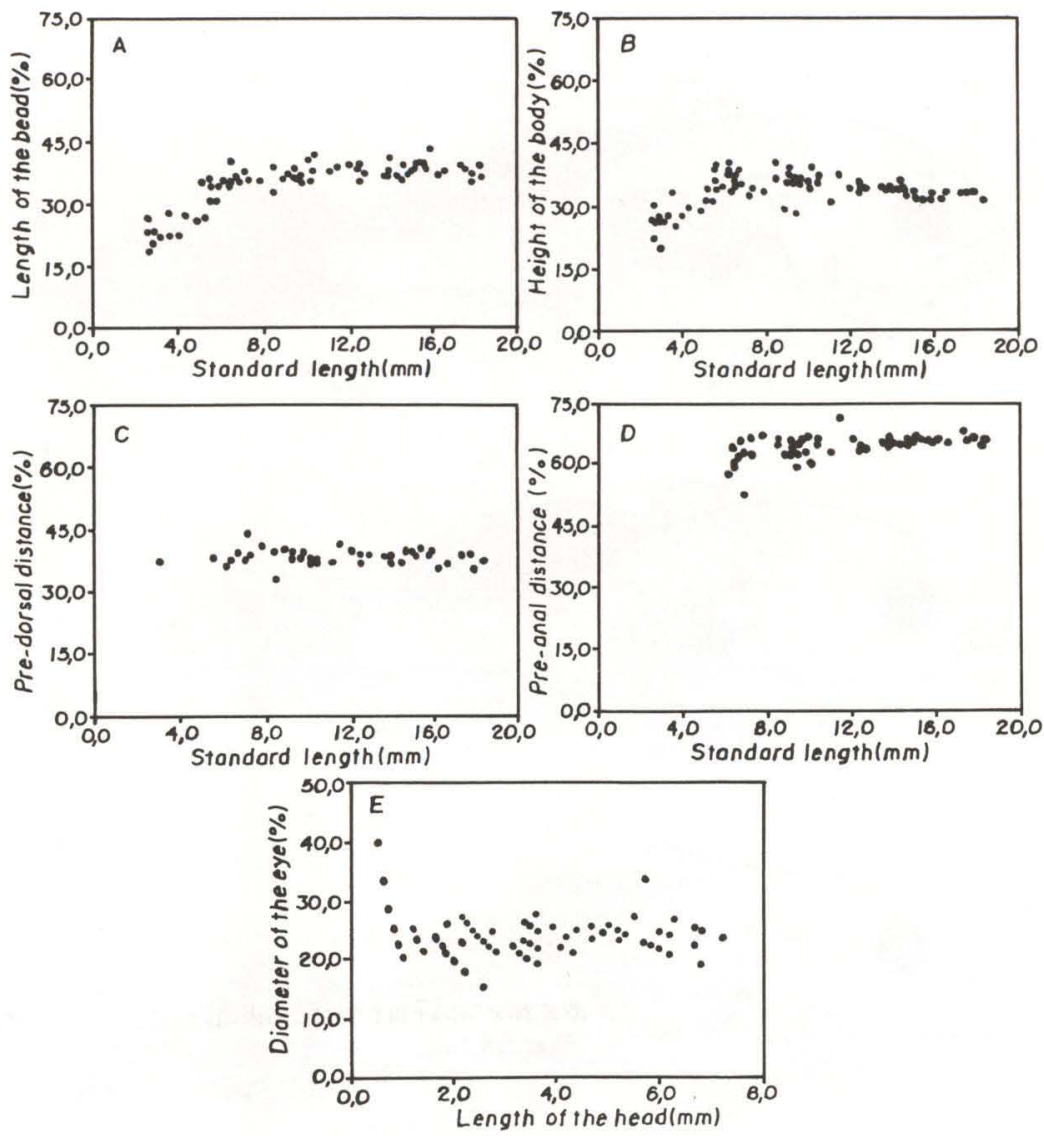

Fig. 3. Relation between: A) length of the head, B) height of the body, C) pre-dorsal distance, D) pre-anal distance and standard length and E) diameter of the eye and length of the head, of Plagioscion squamosissimus (HECKEL, 1840) from Itaipu reservoir.

\section{Morphometric development}

The morphometric development of the larvae showed Person's linear correlation coefficients superior to $0.98(\mathrm{p}<0.001)$ for the length of the head (Fig. 4A), height of the body (Fig. 4B), pre-dorsal distance (Fig. 4C) and pre-anal distance (Fig. 4D) in relation to standard length.

High values of the correlation coefficient $(r=0.98 ; \mathrm{p}<0.001)$ of the linear regression of eye diameter on head length were registered (Fig. 4E).

\section{DISCUSSION}

In many groups, there is much difficulty in distinguishing between larvae of different species. DuNN (1983) describes that the number, structure, position and 

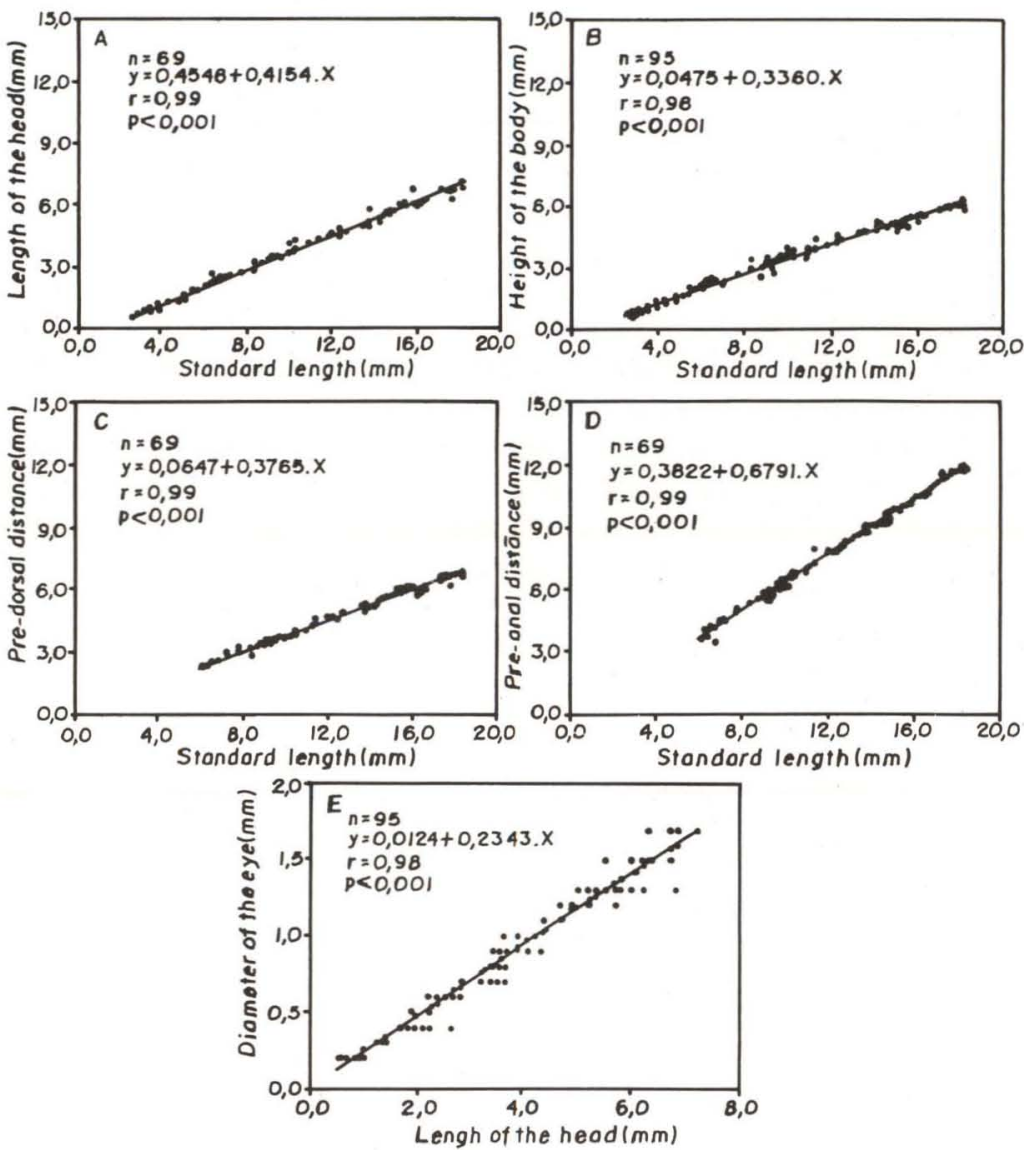

Fig. 4. Linear regression of: A) length of the head, B) height of the body, C) pre-dorsal distance, D) pre-anal distance on standard length and E) eye diameter on head length, of Plagioscion squamosissimus (Heckel, 1840) from Itaipu reservoir.

development sequence of the fins are useful in identifying the larvae of fish at all taxonomic levels, these characteristics being currently used in almost all papers about larval development. On the other hand, ARAUJO-Lima (1984), based on the studies conducted in the Amazon river, verified that larvae of Characiformes are frequently separated from those of Clupeiformes and Sciaenidae by the relation between the maximum height of the body and the total length; and from Siluriformes larvae by the diameter of the eye and pre-anal distance.

Here, the larvae of $P$. squamosissimus were identified based on the sequence of individuals in different stages, from juveniles until recently-hatched larvae. These can be diagnosed by presenting a moderate-sized head, in the specimens with a standard length up to $6 \mathrm{~mm}$, and a large head in specimens over this length. The pectoral fins are situated in a higher position on the body, next to the operculum bones, and the ventral fins, in a thoracic position. The body presents a moderate 
height, in relation to the standard length, and the eyes are small to moderate-sized, in relation to the head. They present a large mouth with caniniform teeth.

The description of the chromatophores in larvae of fish is important, because their number and position are used in the identification of the species (FABER \& GADD 1983). SANTOS (1992) verified that the larvae of "dourado", "piau-verdadeiro", "curimatá-pioa" and "curimatá-pacu" present chromatophores of a dentritic shape; in the larvae of "surubim" they have a puntiform shape; and in the larvae of "pacu" they are puntiform and dentritic. In our studies, the larvae of $P$. squamosissimus present dentritic shaped chromatophores, sparsely distributed in the cephalic region, a character that was used in their identification.

The growth of $P$. squamosissimus in the post-larval and juvenile phases, under controlled cultivation conditions, are progressively proportional to the fish's age (PEIXOTO 1953; WORTHMANN 1983). In the present study, the growth analysis of $P$. squamosissimus also showed proportionality in the variation of the body measurements: between the standard length and length of the head, height of the body, pre-dorsal distance and pre-anal distance; the same tendency between head length and eye diameter was also observed.

ACKNOWLEDGMENTS. We are grateful to Doctors Angelo Antonio Agostinho and Sidney Magela Thomaz and to Cláudia Costa Bonecker for critical reading and suggestions. To Dr. Heraldo Britski, for confirming the identified species. To biologist Kazuko Suzuki for the drawings. To Núcleo de Pesquisa em Limnologia, Ictiologia e Aquicultura (Nupélia) for the facilities conceded. To Itaipu Binacional for financial and logistic support.

\section{REFERENCES}

Agostinho, A.A.; J.R. BoRGHeTti; C.M. DOMANICZKY; S.V.G. NOGUEIRA \& E.K. OKADA. 1989. Produção pesqueira e situação da pesca no reservatório de Itaipu. Anais Seminário Nacional de Grandes Barragens, Foz do Iguaçu, 18: 1059-1075.

Ahlstrom, E.H. \& O.P. BALl. 1954. Description of eggs and larvae of jack mackerel (Trachurus symmetricus) and distribution and abundance of larvae in 1950 and 1951. Fish. Bull. 56: 209-245.

AHLSTROM, E.H. \& H.G. MoseR. 1976. Eggs and la rvae of fishes and their role in systematic investigations and in fisheries. Rev. Trav. Inst. Pêch. Marit. 40 (3): 379-398.

Ahlstrom, E.H.; J.L. Butler \& B.Y. SuMidA. 1976. Pelagic stromateoid fishes (Pisces, Perciformes) of the eastern Pacific: kinds, distributions, and early life histories and observations of five of these from the north-west Atlantic. Bull. Mar. Sci. 26 (3): 285-402.

ANNIBAL, S.R.P. 1983. Avaliação bio-ecológica e pesqueira das pescadas (Plagioscion squamosissimus, Heckel 1840 e Plagioscion montei, Soares 1978) no sistema lago Rei, ilha do Careiro-AM, Brasil. Dissertação de Mestrado, não publicada, Instituto Nacional de Pesquisa da Amazônia, 
Fundação Universidade do Amazonas, Manaus, 114p.

ARAujo-Lima, C.A.R.M. 1984. Distribuição espacial e temporal de larvas de characiformes em um setor do rio Solimões/Amazonas, próximo a Manaus, AM. Dissertação de Mestrado, não publicada, Instituto Nacional de Pesquisa da Amazônia, Fundação Universidade do Amazonas, Manaus, 86p.

CruZ, J.A.; J.A. Moreira; J.R. VERANI; L. GIRARDI \& C.R.C. Torloni. 1990.

Levantamento da ictiofauna e aspectos da dinâmica de populações de algumas espécies do reservatório de Promissão, SP. (1 ${ }^{\mathrm{a}}$ etapa). São Paulo, CESP/UFSCar, 78p.

DUNN, J.R. 1983. The utility of development osteology in taxonomic and systematic studies of teleost larvae: a review. NOAA, Tech. Rep. NMFS Circ. 450: 1-19. FABER, D.J. \& S. GADD. 1983. Several drawing techniques to ilustrate larval fishes.

Trans. Am. Fish. Soc. 112: 349-351.

Fowler, H.W. 1954. Os peixes de água doce do Brasil. Arq. Depto. Zool., São Paulo, 9: 1-399.

FUEM/ITAIPU BINACIONAL. 1989. Relatório do projeto "Ictiofauna e Biologia Pesqueira" (mar/86 - fev/87). Maringá, Fund. Univ. Est. de Maringá, Itaipu Binacional, 478p.

1990a Ecologia de populações de peixes no reservatório de Itaipu, nos primeiros anos de sua formação - $6^{\mathrm{a}}$ etapa (mar/87-fev/88). Maringá, Fund. Univ. Est. de Maringá, Itaipu Binacional, 391p.

1990b. Ecologia de populações de peixes no reservatório de Itaipu, nos primeiros anos de sua formação $-7^{\mathrm{a}}$ etapa (mar/88 -fev/89). Maringá, Fund. Univ. Est. de Maringá, Itaipu Binacional, 617p.

HAHN, N.S. 1991. Alimentação e dinâmica da nutrição da curvina Plagioscion squamosissimus (Heckel,1840) (Pisces, Perciformes) e aspectos da estrutura trófica da ictiofauna acompanhante no rio Paraná. Tese de Doutorado, não publicada, Universidade Estadual Paulista, Rio Claro, 287p.

ITAIPU/BINACIONAL. 1981. Complementação do inventário ictiofaunístico. São Paulo, CETESB, 89p.

Kendall, A.W. JR.; E.H. Ahlstrom \& H.G. Moser. 1984. Early life history stages of fishes and their characters. Spec. Publ. Amer. Soc. Ichthyl. Herpetol. 1: $11-22$.

LEIS, J.M. \& T. TRNSKI. 1989. The larvae of Indo-Pacific shorefishes. Honolulu, University of Hawaii Press, 371p.

Mota, A.; J.D. Rodrigues; E.C. CAmpos \& M.N. DE Moraes. 1984. Captura seletiva da pescada-do-piaui, Plagioscion squamosissimus Heckel, 1840 (Osteichthyes, Sciaenidae), com redes de emalhar, na represa de Bariri, rio Tietê, Estado de S. Paulo. Brasil. Bolm. inst. pesca., São Paulo, 11: 13-23.

NAKATANI, K.; J.D. LATINI; G. BAUMgARTENER \& M.S.T. BAUMGARTNER. 1993.

Distribuição espacial e temporal das larvas de curvina Plagioscions squamosissimus (Heckel, 1840) (Osteichthyes, Sciaenidae), no reservatório de Itaipu. Rev. Unimar 15 (supl.): 191-209.

Nomura, H. 1984. Dicionário dos peixes do Brasil. Brasília, Editerra Editorial, 
$482 \mathrm{p}$.

PEIXOTO, J.T. 1953. Contribuição para o estudo do crescimento da corvina Plagioscion squamosissimus (Heckel, 1840) em cativeiro (Actinopterygii, Sciaenidae). Rev. Brasil. Biol. 13 (2): 173-177.

Ringuelet, R.A.; R.A. Aramburu \& A.A. Aramburu. 1967. Los peces argentinos de agua dulce. Buenos Aires, Comis. Invest. Cient., 602p.

SANTOS, J.E. DOS. 1992. Ontogênese e comportamento larvais de seis espécies de peixes de água doce sob condições experimentais. Dissertação de Mestrado, não publicada, Universidade Federal de Minas Gerais, Belo Horizonte, 132p.

SILVA, S.L. DE O. \& R.S. DE MENEZES. 1950. Alimentação de curvina, Plagioscion squamosissimus (Heckel, 1840) da lagoa de Nazaré, Piauí (Actinopterygii, Sciaenidae). Rev. Brasil. Biol. 10 (2): 257-264.

SOARES, L.H. 1978. Revisão taxonômica dos sciaenideos de água doce da região amazônica brasileira (Osteichthyes, Perciformes, Sciaenidae). Dissertação de mestrado, não publicada, Fundação Universidade do Amazonas Manaus, 88p. Torloni, C.E.C.; J.J. SANTOS; A.A. CARVAlHo JR. \& A.R.A. CorRÊA. 1993. A pescada-do-piauí Plagioscion squamosissimus (Heckel, 1840) (Osteichthyes, Perciformes), nos reservatórios da Companhia Energética de São Paulo -CESP. São Paulo, Série de Pesquisa e Desenvolvimento, 23p.

WORTHMANN, H.D. 1983. A comparative study of the growth of the post larval and juvenile Pescadas Plagioscion squamosissimus (Heckel) and Plagioscion monti (Soares) in a white water lake of the Central Amazon. Amazoniana 7 (4): 465-77.

Recebido em 25.VII.1996; aceito em 13.II.1997. 